\title{
Getting to Know You: Student-Faculty Interaction and Student Engagement in Online Courses
}

\author{
Jennifer Symonds Morrison \\ Murray State University
}

Covid-19 presented many challenges to universities as brick-and-mortar courses were moved to an online format. This work is an unofficial study of learner-instructor interaction and student engagement in two 7week online graduate-level courses conducted in Spring 2020, Fall 2020, and early Spring 2021. Research shows that instructor presence in online courses leads to increased student engagement, as well as motivation, well-being, and academic achievement. Student engagement is shown to have a direct impact on a student's emotional, behavioral, and cognitive successes. This work proposes that increased learnerinstructor interaction in online courses using strategies lead to greater student engagement with the course, and greater student success in overcoming barriers and challenges to online learning.

Keywords: online courses, student engagement, learner-instructor interaction, Covid-19

\section{INTRODUCTION}

With the spread of Covid-19 in the spring of 2020, most, if not all universities, chose to move all their courses online. As quarantines and social distancing continued in various forms around the world, online learning became more of an expectation than an option. Beginning in Fall 2016, it was reported that 31.6\% of higher education enrollments in the United States were in online courses (Seaman, Allen, \& Seaman, 2018). Preliminary numbers state that $97 \%$ of college students switched to online instruction by June 2020 (Educationdata.org), while at the same time, university presidents were concerned with online course challenges such as maintaining student engagement, faculty training in online teaching, student success, and achieving academic standards.

The transition from face-to-face classes to online classes is a challenge under the best of circumstances, but as higher education moves into a 'new normal', faculty development and training can now assist in the event it is necessary to move online again. Organizations, such as Quality Matters (www.qualitymatters. org) and the Online Learning Consortium (www.onlinelearningconsortium) work with universities, faculty, students, researchers, and faculty development administrators to provide the tools, resources, and community that help faculty design, develop and facilitate quality and engaging online courses.

Having taught asynchronous online courses for five years, I have spent a great deal of time learning to produce quality courses for a graduate-level public administration program. At the time our university went into quarantine in mid-March, my three online classes were designed in line with the Quality Matters Rubric, 6th Edition. In the Spring of 2020, I was registered for a series of seven courses taught online through Quality Matters, which, upon passing, would allow me to earn the Quality Matters Teaching Online Certificate that "enables instructors to demonstrate their knowledge mastery of online teaching" (Quality 
Matters, 2020). While many of my colleagues were focusing on moving course material onto the LMS and learning Zoom, my primary focus was on my students. This piece presents my experiences teaching three asynchronous online courses during our Covid-19 quarantine year, particularly regarding learner-instructor interaction and student engagement.

\section{LITERATURE REVIEW}

\section{Learner-Instructor Interaction}

Learner-instructor interaction is not a new topic in academia and the research has shown there to be many benefits. Long before online courses, Chickering and Gamson (1987) found a strong association between learner-instructor interaction and student learning, and that frequent contact outside of class is valuable for student motivation, well-being, and intellectual commitment. Komarraju, Musulkin, and Bhattacharya (2010) discuss the role these interactions play in students' academic progress, motivation, and achievement, though the identity of the aspect of the relationships that are helpful as well as why some faculty are more approachable than others are still unclear. Gray and DiLoreto (2016) found that many online students feel a disconnect from their classmates and instructor. The responsibility for a reconnect falls to the instructor through course structure, content, and feedback (Collis, 1998; Everett, 2015; Muirhead, 2004; Shearer, 2003). The role of the instructor is not just to teach content, but to establish a presence in the course from the beginning, to bring personality into the course content, and ask for and respond to student feedback on the course (Jaggars, Edgecombes, \& Stacey, 2013; Shea, Li, and Pickett, 2006; Tu \& McIssac, 2002).

Cox (2011) in a review of decades of research on learner-instructor interaction, developed two conclusions: "(1) interactions between faculty members and students have positive effects on student outcomes, and (2) such interactions do not occur as regularly as educators might hope" (p. 49). This study was conducted at a brick-and-mortar institution, as opposed to online. Traditionally, the interactions between faculty and students may be limited to office hours, first-year seminars/orientation programs, accidental meetings, university or department social events, or living-learning communities. But if brickand-mortar interaction does not occur frequently enough, do online interactions occur frequently enough?

Newton-Calvert and Arthur (2018) discuss a "myriad of easy" (p. 173) to incorporate teaching presence into an online capstone course: emailing a pre-course toolkit out to students before the course starts, with the syllabus, an instructor introduction, and clear guidelines on instructor communication and availability. While instructor presence looks different online, it can be successful, particularly if the course is developed with the student in mind and focuses on various modes for student learners. Riggs and Linder (2016) developed active learning approaches for the asynchronous online classroom utilizing technological and pedagogical activities to mirror face-to-face teaching methods.

\section{Student Engagement}

As with learner-instructor interaction, student engagement is an often-studied topic and one that has many definitions. Bohemia et al. (1997) defined student engagement as "students' willingness, need, desire, and compulsion to participate in and be successful in the learning process" (p. 294). Upon completing a workshop on student engagement in online courses, Briggs (2015) saw online student engagement as overcoming social, administrative, and motivational barriers to online learning. Dixson's (2015) research measuring student engagement, defined it as "generally, the extent to which students actively engage by thinking, talking, and interacting with the content of a course, the other students in the course, and the instructor... is a key element in keeping students connected with the course and, thus, with their learning" (para 3). Finally, Kahu et al. (2014) stated that student engagement has a direct impact on "a student success and achievement due to a student's emotional, behavioral and cognitive connection to their study" (p. 523).

Martin and Bolliger (2018) reviewed the relationship between interaction and engagement, finding that "engagement is developed through interaction" (p. 206) and when it comes to online learning, supporting that interaction is important. Research has identified three interactions in effective online courses: Moore (1993) identified (1) learner-to-learner interaction, (2) learner-to-instructor interaction, and (3) learner-to- 
content interaction. Lear et al. (2010) found a similar interaction with peers, instructors, and content, which "help online learners become active and more engaged in their courses" (p. 206). Martin and Bolliger's (2018) study, based on Moore's (1993) framework, reviewed the various strategies, and whether age, gender, and years of online learning experience affected the students' perception of the strategies.

\section{Student Engagement}

As with learner-instructor interaction, student engagement is an often-studied topic and one that has many definitions. Bohemia et al. (1997) defined student engagement as "students' willingness, need, desire, and compulsion to participate in and be successful in the learning process" (p. 294). Upon completing a workshop on student engagement in online courses, Briggs (2015) saw online student engagement as overcoming social, administrative, and motivational barriers to online learning. Dixson's (2015) research measuring student engagement, defined it as "generally, the extent to which students actively engage by thinking, talking, and interacting with the content of a course, the other students in the course, and the instructor... is a key element in keeping students connected with the course and, thus, with their learning" (para 3). Finally, Kahu et al. (2014) stated that student engagement has a direct impact on "a student success and achievement due to a student's emotional, behavioral and cognitive connection to their study" (p. 523).

Martin and Bolliger (2018) reviewed the relationship between interaction and engagement, finding that "engagement is developed through interaction" (p. 206) and when it comes to online learning, supporting that interaction is important. Research has identified three interactions in effective online courses: Moore (1993) identified (1) learner-to-learner interaction, (2) learner-to-instructor interaction, and (3) learner-tocontent interaction. Leer et al. (2010) found a similar interaction with peers, instructors, and content, which "help online learners become active and more engaged in their courses" (p. 206). Martin and Bollier's (2018) study, based on Moore's (1993) framework, reviewed the various strategies, and whether age, gender, and years of online learning experience affected the students' perception of the strategies.

\section{Student Satisfaction}

Garrison, Anderson, and Archer (2000) developed a framework with significant elements that help explain student success in online courses: teaching presence, social presence, and cognitive presence. Focusing on teaching presence, focuses on three components of the online course: design and organization, facilitation, and direct instruction (Fiock, 2020). Community of Inquiry combined with an adaptation of Chickering and Gamson's (1987) principle of good practice, list instructional strategies that are common strategies for increasing instructor presence in online courses, such as prompt response to, showing personality, sense of humor, diverse activities, and being active in discussion boards.

Alqurashi (2019) studied factors that "predict and relate to student satisfaction" (p. 134), such as online learning self-efficacy (OLSE), learner-content interaction (LCI), learner-instructor interaction (LII), and learner-learner interaction (LLI). Interaction is critical in all learning, particularly online, whether it's between students, between the student and instructor, or between student and content. Many instructors assume that online courses mean there is no learner-instructor interaction, however, the results of this study show that online learning self-efficacy, learner-content interaction, and learner-instructor interaction are major factors in student satisfaction. While studies have agreed that interaction is a predictor of student satisfaction, there is still disagreement as to which type of interaction is the most significant predictor.

\section{UNOFFICIAL STUDY}

\section{Spring 2020: Under Quarantine}

My university went into quarantine in mid-March 2020 and never came back from Spring Break. University administrators, the Faculty Development Center and the Online Champions (representatives from each college chosen for their experience in online course design) worked to assist faculty in moving all face-to-face classes onto the LMS, Canvas, for online access. Workshops were scheduled to explain various apps or programs, such as Kahoots or FlipGrid, practice using Zoom, which the University had only obtained a license for in Fall 2019, and answer any questions that came up. 
All my classes had been designed directly onto the LMS from the beginning of the semester, so there was noting for me to move online. Initially, I did not make any changes to my courses at all. Once the students 'returned' from Spring Break, it became clear to me that even though I had not had to move any of my courses or course work, there were changes that needed to be made to accommodate graduate and undergraduate students during this challenging period.

- Students were no longer penalized for late work. I let each class know the absolute latest I could accept their work based on when final grades were due to the university. I posted regular announcements (written and video) reminding each class of the due dates.

- Regular videos were posted to the announcements asking students if they were doing okay and reminding students that if there was anything I could do to assist them, to email me and I would do what I could.

- Course workload for each class was reduced. Three of my classes were completely online, to begin with, and demographically, all of my classes were primarily non-traditional or online students with jobs, families, and/or other responsibilities that prevent them from attending class on campus. Not being aware of what was happening on their side of the monitor, the best I could do was reduce their academic workload.

- Redo and resubmit for all assignments with low grades were permitted.

- When a student asked for help or if I noticed an issue and reached out to the student, the student and I worked together to solve the problem for the student to succeed.

\section{Fall 2020 \& Spring 2021: No More Quizzes}

In August 2020, our university opened an e-campus with four graduate programs from the Business School and the Master of Public Administration program. The online courses were switched from 8-week semesters to 7-week semesters and go through a design, development, and review process following the Quality Matters guidelines and rubric. I designed and developed two 7-week courses that began the first day of classes, along with two full-semester courses, one undergraduate online course, and one stacked Zoom class. Both of the 7-week online courses pass the Quality Matters review at 100\%.

I removed and replaced all quizzes with discussion boards in online class A,. Orlando (2017) and Darby and Lang (2019) question the standard instructions that require "respond by this day then come back and respond to two or your peers," because it doesn't "foster stimulated, authentic, and creative social interactions in which students can learn from each other" (Darby \& Lang, 2019, p. 84). In other words, conversations don't normally happen that way. The instructions for my instruction boards read:

Instead of a quiz, let's discuss a real-world situation. For full credit, you will need to respond to the scenario, but you will also need to come back and participate in the discussion by responding to your classmates. In order to receive full credit in your initial response (15 points), you must respond to all three questions (5 points each). You must come back and respond to at least one of your peers before the discussion closes (5 points). Once the discussion closes, it will be locked, and no late submissions will be accepted. Responses to classmates such as "I agree!" "Great idea." and "Awesome!" are not considered responses. Your responses are expected to contain substance and explain why you agree or disagree. Supporting your response(s) with the course readings would be ideal!

Students commented that they preferred the discussion boards to quizzes, and by incorporating the module topics into the discussion board, additional assignments were unnecessary. Students also communicated that they did feel a sense of community in the discussion boards, which is important for student-student interaction in online courses. 


\section{Fall 2020 \& Spring 2021: Getting to Know You}

Instead of assigning a whole research paper in a 7-week course, particularly in an introductory public administration course, I only assigned the first part of the paper. Many of these students, non-traditional students, were returning to school after several years and unfamiliar with academic research, how to find academic research, what a literature review is, etc. The assignment was broken down into parts and a different part was assigned in each module to explain how to do academic research, what is considered academic research, developing a literature review, etc. Wray and Montgomery (2019) agree that nontraditional students deserve additional attention and discuss a webinar series that scaffolded research topics allowing students to develop the research skills needed to succeed.

One portion of the assignment required each student to meet with me. The meetings would run from 5 minutes to half an hour, and were two-fold: one, it allowed me to get to know the students a little bit, and two, see how they were doing on their paper. After a greeting, my first question was, "Why did you decide to join our program?" We would discuss why the student applied to the program and plans upon graduation. Course suggestions may be offered, questions answered, and then the paper was discussed.

According to Lowenthal, Snelson, and Dunlap (2017), there is very little literature on video-based communications (i.e., Zoom, Skype, Google Hangouts) in asynchronous online courses. In an attempt to alleviate this issue, a study was conducted in a fully online asynchronous graduate program, where the idea of office hours was redesign to meet the needs of students and better support student learning. An earlier study by Cole, Shelley, and Swartz (2014), in a three year study of over 500 online students, found that the lack of interaction was a reason for student dissatisfaction, concluding that "positive interaction, with the instructor and with fell students seems to go hand-in-hand with student satisfaction" (p. 130).

Students were told to make appointments at their convenience using my Calendly link, and if my schedule did not work with theirs, to email me 2-3 times that did work, including evenings and weekends, and I would schedule the time from my end. I did end up meeting with a couple of students after $5 \mathrm{pm}$. Many students were nervous about meeting with me face-to-face but within a few minutes, the conversations were easy flowing and there was some laughter. In some conversations, I shared my screen with the student to explain something or share additional resources. In a few minutes, I feel as though I really get to know the student, why they are in our MPA program and their future plans, when my original intention was only to help with an assignment.

\section{Fall 2020 \& Spring 2021: Interactions}

For Online class B, Public Organizations, I found an assignment online that I redeveloped as my own. The Imagination Organization Project (IOP) requires students to create a public sector organization based on the topics covered (i.e., power and politics, leadership, organizational culture, etc). Students were given the tools and allowed to build the organization however they chose. For Summer 2020 and Spring 2021, students were to create an organization related to Covid-19. Most students created a non-profit agency that assisted the community in some way. For Summer 2021, student were required to create a government organization related to the Infrastructure Bill. Whatever the instructions, this assignment encourages learner-to-content engagement in several ways. First, it enhances 'real-world application to enhance subject mastery and critical thinking skills' (Martin \& Bolliger, 2018, p. 209). It allows students to examine the task from different perspectives, and this particular activity engages the student giving them a certain amount of control over the assignment. The final assignment is a presentation of the project, to practice speaking to a camera in preparation for the Capstone presentation.

Many of the suggestions made to encourage interaction between faculty and students, I have been doing for over a year. I email online students two weeks and then one week before classes start with a copy of the syllabus. During the semester, I regularly remind students that their emails go into my cell phone and that I will respond to their emails relatively quickly. I end all my videos with "And as always, if there is anything I can do to help, please do not hesitate to email me or make an appointment with me using my calendly link."

I believe that the interactions between the students and myself in these two classes have had a positive impact on student learning. I have received student feedback and comments such as: 
- "I wasn't sure if I was doing the assignment right and then I watched your video..."

- "I have never had a professor meet with me online like this before."

- "Dr. M, you were the only professor (this spring) to ask me how I was doing."

- "I feel so much less stressed since there are no late penalties."

- "Thank you for being so lenient on due dates."

- "Thank you for letting me redo that assignment."

\section{CONCLUSION}

While moving courses online during the pandemic was stressful, for me it was an opportunity to focus on student engagement. By making accommodations for all students from the very beginning, I attempted to take some stress out of an extremely stressful situation. The impact was that these changes are now a standard part of all my classes, online or face-to-face. I also believe that these interactions have helped with student engagement. There is a sense of community (student-student interaction) that I feel when I grade the discussion boards, which in general, have high response rates and quality responses, that I haven't see in previous semesters. In the 'Help Each Other' discussion boards, students are respectful, thoughtful, and helpful in the assistance provided to their peers. And based on the number of emails I receive from students regularly, I know that these students are putting a lot of work into these classes. As their professor, it is my job to be there for them and to help them succeed, and to make that they are, indeed, satisfied.

\section{REFERENCES}

Alqurashi, E. (2019). Predicting student satisfaction and perceived learning within online learning environments. Distance Education, 40(1), 133-148. doi: 10.1080/01587919.2018.1553562

Anderson, T. (2003). Modes of interaction in distance education: Recent developments and research questions. In M.G. Moors \& W.G. Anderson (Eds.), Handbook of Distance Education (pp. 129144). Mahwah, NJ: Lawrences Erlbaum Associates Inc.

Bohemia, L., Beluza, L., Demeester, D., Elander, K., Johnson, M., \& Sheldon, B. (1997). The impact of teaching strategies on intrinsic motivation.

Briggs, A. (2015). Ten ways to overcome barriers to student engagement online. Online Learning Consortium.

Chickering, A.W., \& Gamson, Z.F. (1987). Seven principles for good practices in undergraduate education. AAHE Bulletin, 3(7).

Collis, B. (1998). New didactics for university instruction: Why and how? Computers and Education, 31(4), 373-393.

Cox, B.E. (2011). A developmental typology of faculty-student interaction outside the classroom. New Directions for Institutional Research, 2001(S1), 49-66.

Darby, F., \& Lang, J.M. (2019). Small teaching online: Applying learning science in online classes. John Wiley \& Sons.

Distance Learning Statistics. (2021). Online EDication Statistics. Retrieved from https://educationdata.org/online-education-statistics

Dixson, M.D. (2015). Measuring student engagement in the online course: The Online Student Engagement Scale (OSE). Online Learning, 19(4), n4.

Everett, D.R. (2015). Adding value: Online student engagement. Information Systems Education Journal, $13(6), 68$.

Fiock, H.S. (2020). Designing a community of inquiry in online courses. International Review of Research in Open and Distributed Learning, 21(1), 135-153.

Garrison, D.R., Anderson, T., \& Acher, W. (2000). Critical inquiry in a text-based environment: Computer conferencing in higher education. The Internet and Higher Education, 2(2-3), 87-105. 
Gray, J.A., \& DiLoreto, M. (2016). The effects of student engagement, student satisfaction, and perceived learning in online learning environments. International Journal of Educational Preparation, $11(1), \mathrm{n} 1$.

Jaggars, S.S., Edgecombe, N., \& Stacey, G.W. (2013, April). Creating an effective online instructor presence. Community College Research Center, Columbia University.

Kahu, E.R., Stephens, C.V., Zepke, N., \& Leach, L. (2014). Space and time to engage: Mature-aged distance students learned to fit study into their lives. International Journal of Lifelong Education, 33(4), 523-540. doi: 10.1080/02601370.2014.884177

Kara, M., Kukul, V., \& Cakir, R. (2021). Self-regulation in three types of online interaction: How does it predict online pre-service teachers' perceived learning and satisfaction? The Asian-Pacific Education Researcher, 30(1), 1-10. doi: 10.1007/s40299-020-00509-x

Komarraju, M., Musulkin, S., \& Bhattacharya, G. (2010). Role of student-faculty interactions in developing college students' academic self-concept, motivation, and achievement. Journal of College Student Development, 51(3), 332-342.

Lear, J.L., Ansorge, C., Steckelberg, A. (2010). Interactivity/community process model for the online education environment. Journal of Online Learning and Teaching, 6(1), 71-77.

Moore, M.J. (1993). Three types of interaction. In K. Harry, M. John, \& D. Keegan (Eds), Distance Education Theory (pp. 19-24). New York: Routledge.

Muirhead, B. (2004). Encouraging interaction in online classes. International Journal of Instructional Technology and Distance Learning, 1(6), 45-50.

Quality Matters. (2020). Teaching online certificate. Retrieved from https://www.qualitymatters.org/professional-development/toc

Riggs, S.A., \& Linder, K.E. (2016). Actively engaging students in asynchronous online classes. IDEA Paper \#64. Idea Center, Inc.

Seaman, J.E., Allen, I.E., \& Seaman, J. (2018). Grade increase: Tracking distance education in the United States. Babson Survey Research Group.

Shea, P., Li, C.S., \& Pickett, A. (2006). A study of teaching presence and student sense of learning community in fully online and web-enhanced college courses. The Internet and Higher Education, 9(3), 175-190.

Shearer, R.L. (2003). Interaction in distance education. Special Report, 2(1). Madison, WI: Atwood Publishing.

Sorenson, C.K., \& Baylen, D.M. (2009). Learning online: Adapting the seven principles of good practice to a web-based instructional environment. In A. Orellana, T.L. Hudgins, \& M. Samonson (Eds.), The perfect online course: Best practices for designing and teaching (pp. 69-86). Charlotte, NY: Information Age Publishing.

Tu, C., \& McIssac, M. (2002). The relationship of social presence and interaction in online classes. The American Journal of Distance Learning, 16(3), 131-150.

Umbach, P.D., \& Wawrzynski, M.R. (2005). Faculty do matter: The role of college faculty in student learning and engagement. Research in Higher Education, 46(2), 153-184. doi: 10.1007/s11162004-1598-1

Wray, C.C., \& Montgomery, R.C. (2019). Bridging the Skill Gap: Helping Non-Traditional Students Develop Research Skills When They Need It Most. Adult Higher Education Alliance. 